\title{
セロトニン3受容体拮抗薬 Y-25130のラット胃運動に及ぼす影響
}

\author{
小谷 直也，芳賀慶一郎，瀬戸口通英 \\ 吉富製薬（株）中央研究所* \\ (1992年 9 月 22 日)
}

\begin{abstract}
要約：選択的なセロトニン 3 受容体拮抗薬である Y-25130 のラット胃運動に及ぼす影響を検討した。胃 運動は，新たに開発した胃運動自動解析システムで (1) motility index（MI：運動指数), (2) amplitude (AM: 収縮力)，(3) frequency（FR: 収縮頻度）の 3 つの成分に分けて解析した，Y-25130は $1 \mu \mathrm{g} / \mathrm{kg}$ 以上の静脈内投与で MI および AM をえ進した. 5 - $\mathrm{HT}_{3}$ 受容体拮抗作用を示す ondansetron およびメ トクロプラミドでも同様の作用が認められたが，Y-25130に比べて弱かった．シスプラチンの $10 \mathrm{mg} / \mathrm{kg}$ の静脈内投与は $\mathrm{MI}$ および $\mathrm{AM}$ を抑制し, $\mathrm{Y}-25130$ は $1 \mu \mathrm{g} / \mathrm{kg}$ 以上でシスプラチンによって抑制された MI および AM を回復させた．それらの作用は ondansetron とほぼ同等であり，メトクロプラミドに 比べて強かった．Y-25130で認められた胃運動え進作用はアトロピン処置および迷走神経切除によって消 失し, capsaicin の前処置は Y-25130 の元進作用を抑制した。 また, 迷走神経の求心性電気刺激によっ て誘発された胃の収縮は Y-25130 で增強されたが，遠心性刺激によって誘発された収縮は影響されなかっ た．以上のように，Y-25130は胃自動運動を亢進させ、シスプラチンで抑制された胃運動を回復させた. その胃運動元進作用は迷走神経を介するものであり, 作用点は迷走神経求心性線維に存在するセロトニン 3 受容体であることが推察された.
\end{abstract}

\section{緒言}

近年，セロトニン（5-HT）受容体のサブタイプに関 する研究が進展し, Gaddum and Picarelli1) によっ て命名されたセロトニン M 受容体は, Richardson and Engel ${ }^{2)}$ によってセロトニン $3\left(5-\mathrm{HT}_{3}\right)$ 受容体 として分類されるようになった。

強力かつ選択的な $5-\mathrm{HT}_{3}$ 受容体遮断作用を有するY$25130(( \pm)-\mathrm{N}-(1$-azabicyclo [2.2.2] oct-3-yl) -6chloro-4-methyl-3-oxo-3, 4-dihydro-2H-1, 4, benzoxazine-8-carboxamide monohydrochloride) ${ }^{3)}$ はイ 又およびフェレットにおける抗悪性腫場剤誘発嘔吐に対 して, 強力な制吐作用を示すことが報告されている4). 今回, Y-25130 の制吐作用との関連から, ウレタン麻醉 ラットの胃自動運動，および嘔吐を誘発する代表的な抗 悪性腫噋剤であるシスプラチン投与時の胃運動に及ぼす 影響を検討した。 さらに，同じ $5-\mathrm{HT}_{3}$ 受容体抬抗作用 を示す ondansetron ${ }^{5)}$ および消化管運動調整薬でやは り $5-\mathrm{HT}_{3}$ 受容体拮抗作用を示すメトクロプラミド 6 )

${ }^{*} \mathbf{\top} 871$ 福岡県築上郡吉富町小祝 955
と比較検討し, 作用点についても若干の検討を行った. ラットの胃運動は, その運動波形が比較的複雑である ことから,これを数值化して客観的に評価する自動解析 装置を作製する試みはほとんど行われていない，そのた め, ラット胃運動における薬効評価は肉眼的観察という 実験者の主観的な評価にとどまっているものが少なくな い. そこで我々は, ラット胃運動波形をデジタル変換し てコンピューターによって解析し, 胃運動を数值化して 評価する胃運動自動解析システムを新たに作製した。今 回の胃運動の評価は本システムを用いて行った.

\section{実 験 方 法}

\section{1. 使用薬物}

Y-25130 の化学構造式を図 1 に示す. Y-25130（自社 合成), ondansetron (自社合成), 塩酸メトクロプラ ミド（メトクロプラミド, Sigma）扔よび硫酸アトロ ピン（アトロピン, Sigma）は生理食塩液に溶解し, シスプラチン（Sigma）は生理食塩液に加温溶解し使 用した. capsaicin（ナカライテスク）は10\%エタノー ル (キシダ化学) および $10 \%$ Tween 80 （石津製薬） を含む生理食塩液に, カルバミン酸エチル（ウレタン, 


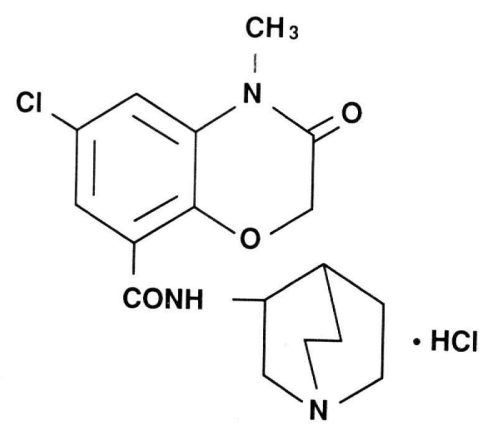

Fig. 1 Chemical structure of Y-25130.

キシダ化学）は蒸留水に溶解した.

\section{2. 使用動物}

試験には雄性 Wistar ラット（体重 $220 \sim 350 \mathrm{~g}$, 成 和実験動物研究所）を使用した。試験開始 18 時間前か ら絶食（水は自由摄取）し, ウレタン $1.5 \mathrm{~g} / \mathrm{kg}$ 皮下投 与で使用した。

\section{3. 胃運動測定法}

バルーン法を用いて測定した．前胃部分を小切開し直 径約 $2 \mathrm{~cm}$ のゴム製バルーンを胃幽門前庭部に挿入留置, バルーン内に水 $1 \mathrm{ml}$ を注入して, カニューレを介し圧 カトランスデューサーに接続した。 バルーンの内圧変化 をポリグラフ（360 型, 日本電気三栄）を介して，デー タレコーダー（SR-31，TEAC）およびペンレコーダー （561 型，日立製作所）に記録した。また，同時に胃運 動自動解析システムのハードディスク（LHD-38VS, ロジテック）に運動波形を取り込んだ（図 2 ).

\section{4. 運動波形解析法}

図 2 に示したように, バルーン法によって得られた胃 運動の波形を $\mathrm{AD}$ コンバーターを介し，デジタル化し て解析システムのハードディスクに $100 \mathrm{msec}$ のサンプ リング・タイムで入力した，また，デー夕保存のために 光ディスク（PC-OD101 および PC-OD101-01， NEC） に記録した。図 3 に示したように, 運動は (1) motility index (運動指数), (2) amplitude（収縮力), (3) frequency（収縮頻度）の3つの成分に分けて解析した。

(1) motility index (以下 MI と略す) : 運動波形を個々 の収縮に分割し, 各々の収縮における極小点の Y座標と 運動波形に囲まれる面積を求め，それを合計した。

(2) amplitude（AM）: 個々の収縮における極大点之 極小点の $\mathrm{Y}$ 座標の差を求め, その平均值を算出した.

(3) frequency（FR）: 個々の収縮の総回数. 各成分 について 10 分毎に解析を行い，被験薬投与前の 10 分間 computer system

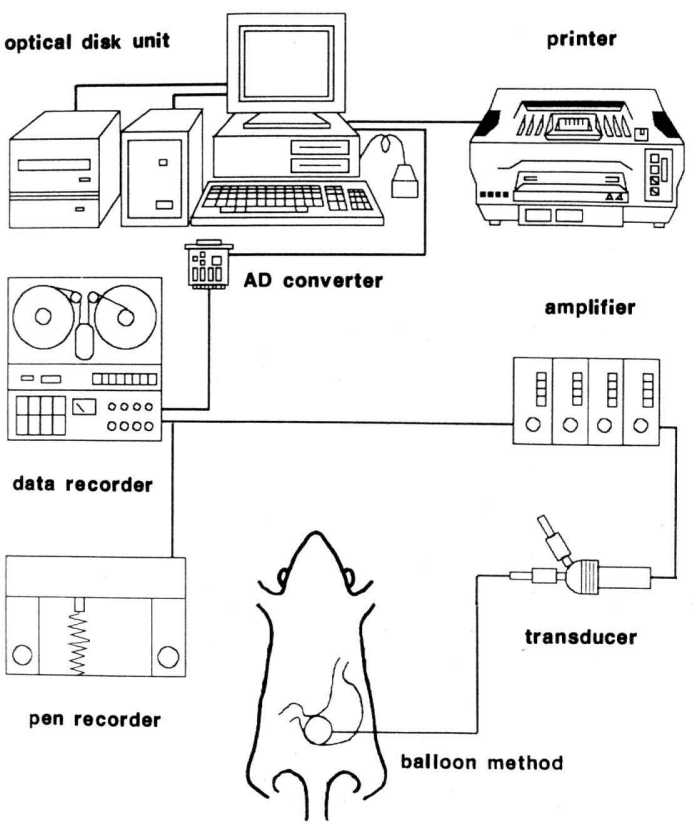

Fig. 2 Schema of the automatic analyzing system for gastric motility in an anesthetized rat.

値を基準に，投与後の各值を\%変換し表示した.

本自動解析システムによる解析結果と, 実験者のマニュ アルによる解析結果との相関を検討する目的で, 一部, マニュアルによる解析を行った．MI はペンレコーダー によって描かれた運動波形をコピーした用紙を波形に沿っ て切り取り, 電子天秤（H51，ザルトリウス）によって 重量を計測した。 AM および FR は area curvimeter （X-PLAN $360 \mathrm{i}$ ，牛方商会）を用いて，収縮高（長さ） および頻度（回数）を計測した。

\section{5。胃自動運動に及ぼす影響}

胃の自動運動に及ぼす各被験薬の影響は，30 分間の コントロール測定後, 被験液を静脈内投与し, 投与後 60 分間運動を測定した.

\section{6.シスプラチン誘発胃運動抑制に及ぼす影響}

シスプラチン誘発胃運動抑制に及ぼす各被験薬の影響 は, 30 分間の自動運動測定後, シスプラチン $10 \mathrm{mg} / \mathrm{kg}$ を静脈内投与し, 約 50 分後に被験液を静脈内投与して, 60 分間運動を測定した。

\section{Y-25130 の迷走神経切除時の胃運動および迷走神経} 電気刺激誘発，胃収縮に及ぼす影響

ラットの両側頸部で迷走神経を剥離切断し，胃運動を 


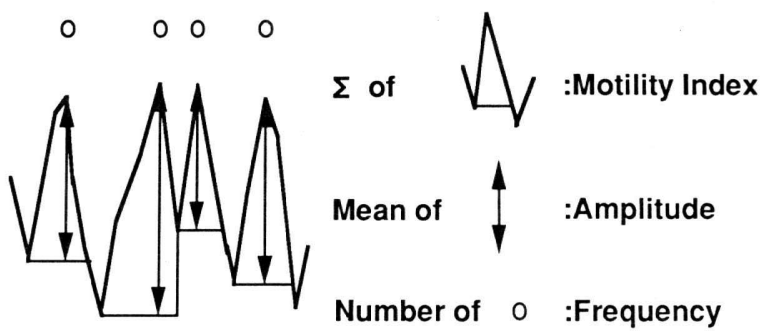

Fig. 3 Schematic waves showing how the analyzing system computes motility index, amplitude and frequency.

観察した。運動安定後, 刺激装置 (SEN-3301, 日本光 電）を介して左側迷走神経に遠心性電気刺激 $(5 \mathrm{~Hz}, 1$ msec， 5V）を 15 秒間加えた.

また, 同様にラットの左側頸部で, 迷走神経を剥離し て末梢側を切断し, 中枢側を求心性に電気刺激を加えた.

何れの電気刺激も 15 分間隔で行い, 得られる胃収縮 が安定後, 刺激の 5 分前に Y - 25130 を静脈内投与し, 投与後 $5,20 ， 35$ および 50 分の電気刺激で誘発される 胃収縮を測定した。電気刺激で誘発される胃運動はほ之 んよ゙が単発性収縮であったので, 評価は AM のみを測 定し, Y-25130 投与前の 2 回の AM の平均を基準に, 投与後の $\mathrm{AM}$ を\%変換して評価を行った.

\section{8、Y-25130 の作用に及ぼすアトロピンの影響}

自動運動安定後, Y-25130 $100 \mu \mathrm{g} / \mathrm{kg}$ を, 10 分後にア トロピン $100 \mu \mathrm{g} / \mathrm{kg}$ を各々静脈内投与し, 胃運動を観察 した.

\section{Y-25130 の作用に及ぼす capsaicin の影響}

6 週令のラットに capsaicin $25,50,100 \mathrm{mg} / \mathrm{kg}$ を 3 日間連続皮下投与し, 最後の投与から $13 \sim 14$ 日後に 供試した。試験前日に capsaicin $0.33 \mathrm{mM}$ 溶液を 1 滴点眼して，目を拭うワイピングの動作を示したもの は, 求心性線維が遮断されていないものとして試験から 除外した. 30 分間の自動運動測定後, Y-25130を静脈 内投与し，投与後 30 分間運動を測定した.

\section{0. 統計解析}

結果は平均值士標準誤差で表し, 被験薬投与前値との

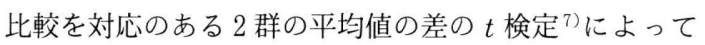
有意水準 5 および $1 \%$ で検定した。

\section{実 験 結 果}

\section{1. 解析システムの作製}

バルーン法で得られた胃運動波形にはラット自身の呼 吸等による振動，電気的なノイズなどのアーチファクト
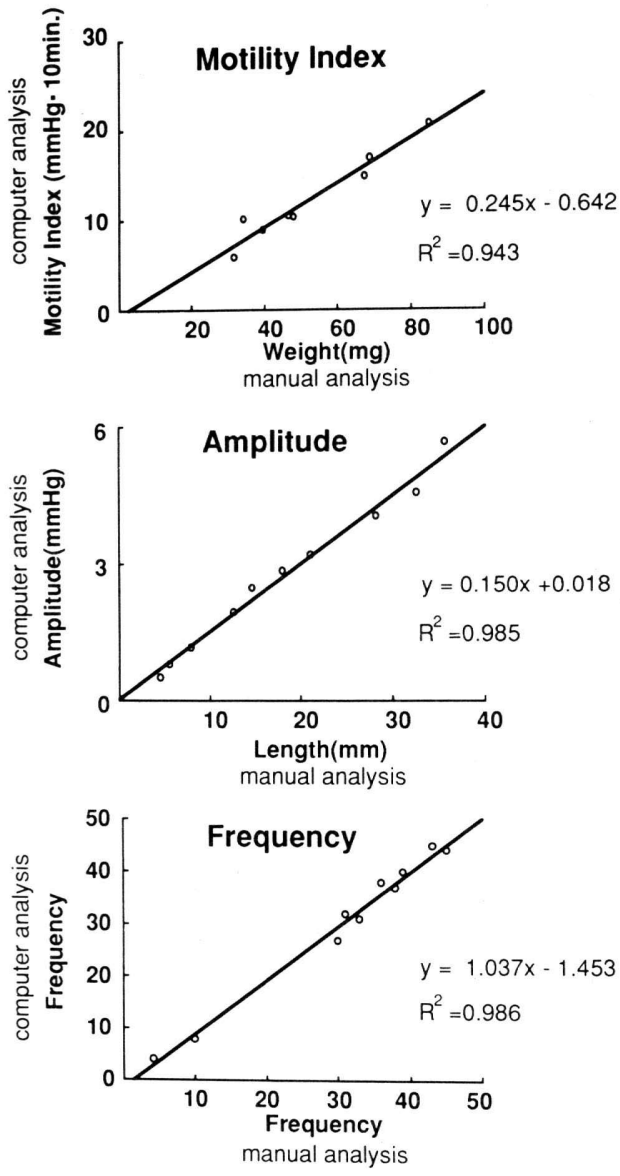

Fig. 4 Correlation between computer analysis and manual analysis of gastric motility.

が含まれておりこれらのアーチファクトを除去するた めに, $100 \mathrm{msec}$ でサンプリングしたデータを 20 個すな わち 2 秒間分累積させた。これによって，ペンレコーダー に描かれた原波形にほぼ忠実な波形を得ることができた. このようにして得られた波形の個々の変曲点間の $\mathrm{Y}$ 座 標の差を一定以上もたせて極大值, 極小值を認識させる ことによって，1回の収縮とした．

胃運動自動解析システムによる解析結果とマニュアルに よる解析結果との相関を図 4 に示す. MI, AM および FR の相関係数 $\left(\mathrm{R}^{2}\right)$ はそれぞれ $0.943 ， 0.985$ および 0.986 と,いずれも高い值を示した。

\section{2. 胃自動運動に及ぼす影響}

自動運動に対する Y-25130, ondansetron およびメ トクロプラミド静脈内投与の影響を図 5 および 6 に示す. $\mathrm{Y}-25130$ は $1 \mu \mathrm{g} / \mathrm{kg}$ 以上で AM を, 1 および $10 \mu \mathrm{g} / \mathrm{kg}$ 


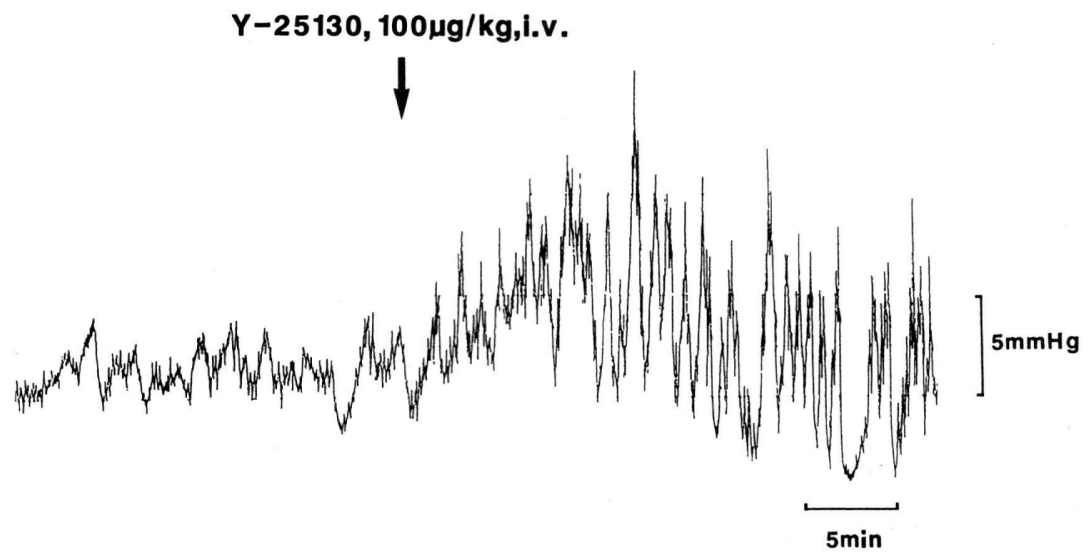

Fig. 5 Effect of Y-25130 on gastric motility in an anesthetized rat.

で MI を増大させた. ondansetron は $10 \mu \mathrm{g} / \mathrm{kg}$ 以上 で,メトクロプラミドは $100 \mu \mathrm{g} / \mathrm{kg}$ でいずれむ MI お よびAMを増大させた．また，いずれの被験薬もFRに は著しい影響を及ぼさなかった。

\section{3. シスプラチン投与下の胃運動に及ぼす影響}

シスプラチン投与下の胃運動に対する Y-25130, ondansetron およびメトクロプラミド静脈内投与の影響を 図 7 および 8 に示す. シスプラチン $10 \mathrm{mg} / \mathrm{kg}$ の投与 によって MI および AM は抑制され，シスプラチン投 与後約 2 時間持続した。 これに対し，Y-25130 および ondansetron は $1 \mu \mathrm{g} / \mathrm{kg}$ 以上で,メトクロプラミドは $100 \mu \mathrm{g} / \mathrm{kg}$ 以上でいずれあ MI および AM を増大させ た。 また, FR はシスプラチンの投与によって一過性に 抑制され，被験薬によって回復がみられる場合があった が, 用量反応性は明らかでなかった。

\section{Y-25130 の迷走神経切除時の胃運動および迷走神経}

\section{電気刺激誘発胃収縮に及ぼす影響}

迷走神経切除下胃運動に対する Y-25130 静脈内投与 の影響を図 9 に示す．Y-25130 $100 \mu \mathrm{g} / \mathrm{kg}$ は迷走神経 切除下の胃の自動運動に影響を及ぼさなかった。

また，迷走神経電気刺激誘発胃収縮に対する Y - 25130 静脈内投与の影響を図 9 および図 10 に示す。迷走神経 の遠心性電気刺激で誘発される胃収縮に対して Y - 25130 は影響を及ぼさなかった。一方, 迷走神経の求心性刺激 では Y-25130 $100 \mu \mathrm{g} / \mathrm{kg}$ の投与によって胃収縮の元進 が認められた.

\section{5．Y-25130 の胃運動亢進作用に及ぼすアトロピンの影}

\section{響}

Y-25130 の静脈内投与による胃運動六進作用に及ぼす
アトロピンの影響を図 11 に示す. Y-25130 $100 \mu \mathrm{g} / \mathrm{kg}$ の投与によって六進された胃運動はアトロピンの $100 \mu \mathrm{g}$ /kg の投与によって完全に抑制された.

\section{Y-25130 の胃運動亢進作用に及ぼす capsaicin の} 影響

capsaicin を前処置したラットの胃運動に対する Y25130 静脈内投与の影響を図 12 に示す. capsaicin 前 処置によって, Y-25130 の 1,10 および $100 \mu \mathrm{g} / \mathrm{kg}$ の投 与による胃運動穴進作用は消失した.

\section{考察}

ラットの胃運動はその運動波形が比較的複雑であるた め, 対応できる解析システムは現在市販されていない. そのため実験者の主観的な評価によるものが少なくなかっ た. 今回我々は, ラット胃運動の自動解析システムの作 製を試みた。胃運動を評価する場合 (1) 運動量の積分値 として motility index (MI), (2) 収縮力として amplitude (AM), (3) 収縮頻度として frequency（FR）の 3 つの成分が重要であると考え, これらに分けて解析し た. 完成した自動解析システムによる解析結果とマニュ アルによる解析結果とはいずれの成分とも高い相関を示 し, 今回開発した胃運動自動解析システムの有用性が示 された.

Y-25130 は選択的な $5-\mathrm{HT}_{3}$ 受容体拮抗薬 ${ }^{3)}$ であり, 抗悪性腫瘍剂誘発嘔吐に対して強力な制吐作用 ${ }^{4)}$ を示す ことが明らかにされている，嘔吐は消化管運動からみれ ば, 逆蠕動運動であり, 制吐作用を示す薬物が胃排出な

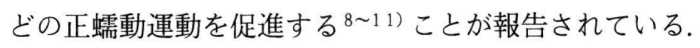
そこで, Y-25130 の麻酔ラットの胃自動運動, および嘔 

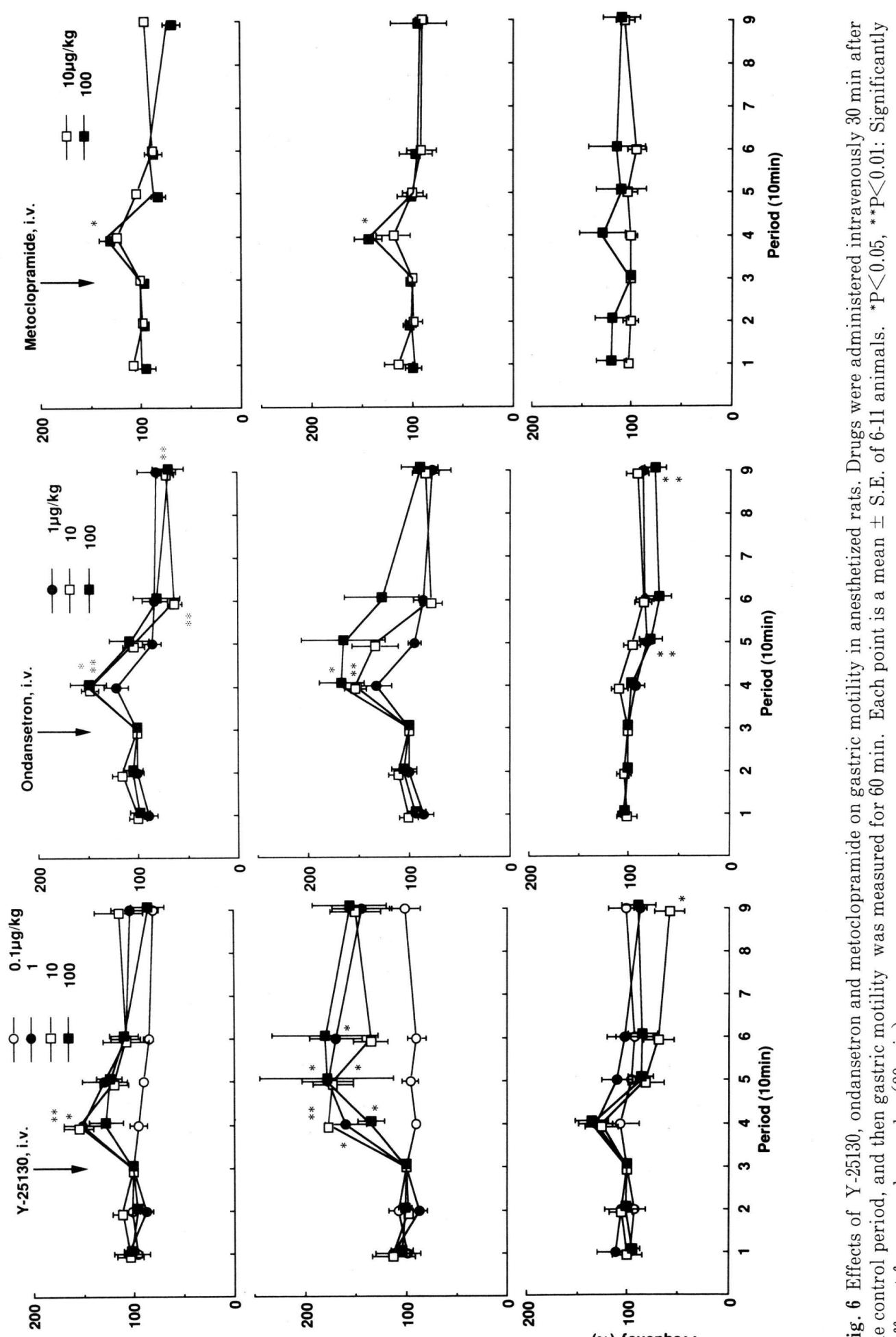

(\%) xәрu| К‼!!ow

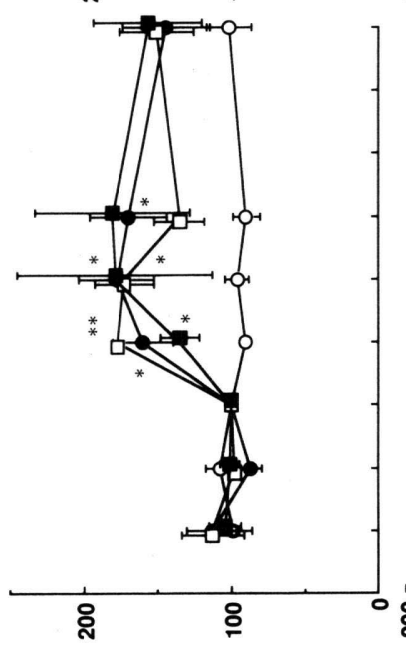

(\%) әрnџ!|duళ

(\%) Kouenbedy

ट्रे

近

व्ल

壱

के

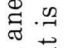

$\Xi . ష ్$

离起

도

密离

ธี के

월

हี

응 ⿷匚

范

घี

ฮี

도욜

茕.

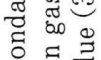

के

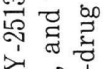

$\checkmark$ ¿

तै है

훈혀

0 范

我密 


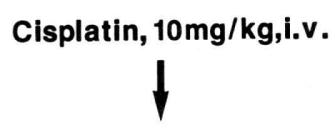

Y-25130, 10 $\mu \mathrm{g} / \mathrm{kg}, \mathrm{i} . \mathrm{v}$.

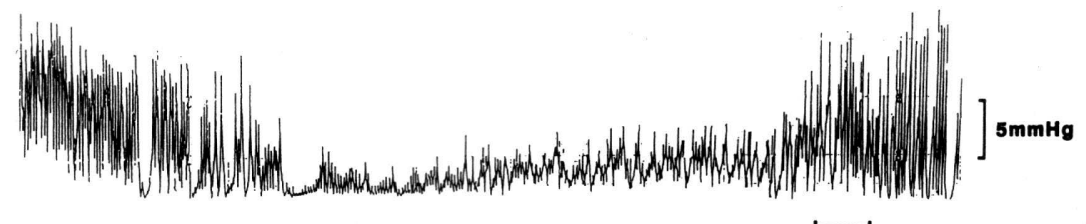

5min

Fig. 7 Effect of Y-25130 on gastric motility reduced by cisplatin in an anesthetized rat.

吐を誘発する代表的抗悪性腫瘍剂であるシスプラチン投 与時の胃運動に及ぼす影響を, 新規に開発した解析シス テムを用いて検討した.

$\mathrm{Y}-25130$ は自動運動の MI および $\mathrm{AM} を 1 \mu \mathrm{g} / \mathrm{kg}$ 以 上で増大させた。 その作用は $5-\mathrm{HT}_{3}$ 受容体拮抗作用を 示す ondansetron およびメトクロプラミドでも同様に 認められたが，いずれと比べても Y-25130の方が強かっ た.

一方，シスプラチンは胃運動を抑制した。 ラットは嘔 吐しない動物 ${ }^{12)}$ として知られており, シスプラチン投 与によっても逆蠕動運動が惹起されなかったものと推察 される. 胃運動が抑制されたことについては, シスプラ チンが胃排出を抑制する ${ }^{13)}$ との報告があり, 正蠕動運 動が抑制された可能性が考えられる、Y-25130はシスプ ラチンで抑制された $\mathrm{MI}$ 抢よび $\mathrm{AM}$ を $1 \mu \mathrm{g} / \mathrm{kg}$ 以上で 回復させ, その作用は ondansetron とほぼ同等であり, メトクロプラミドに比べ低用量から認められた．これらの結 果は, $5-\mathrm{HT}_{3}$ 受容体拮抗薬が胃排出を促進 $\left.8 \sim 11\right)$ し, シ スプラチンで遅延した胃排出を改善する1 ${ }^{3)}$ という報告 との関連性を示唆するものと考えられる. さらに, 吐き 気や食欲不振などの消化器症状を示す胃炎患者では胃運 動低下が認められており, 胃運動の交進はこれらの消化 器症状の改善につながると考えられる14)，Y-25130は 自動運動のみならずシスプラチンで抑制された胃運動を も改善しており, 制癌剂投与時の消化器症状に有用であ る可能性が考えられる.

自動運動あるいはシスプラチン投与下胃運動のいずれ においてむ，Y-25130 および ondansetron の高用量投 与群では, 胃運動を強力に六進した後（投与後 20 分以 降）から $\mathrm{AM}$ の平均值は増大したが有意差が認められ ない場合があった。これは薬物の用量反応性がベル型を 示しており, 同時期に作用の消失する例が混じたために, バラッキが大きくなり有意差が認められなかったものと
考えられる. 既存の消化管運動調整薬の用量反応性がベ ル型を示す ${ }^{15)}$ ことが報告されており，今回の用量反応 性との関連が推察される.

Y-25130 の胃運動六進作用はアトロピンの処置によっ て完全に消失した。また，迷走神経切除下ラットにおい ては Y-25130 の胃運動元進作用は認めらなかった. 従っ て, Y-25130 の胃運動元進作用にはコリン作動性神経, 即ち迷走神経の関与が示唆される.

capsaicin は赤トウガラシに含まれる刺激性成分で, その高用量の皮下投与は神経伝達物質を枯渴させること により, 求心性神経線維を遮断する ${ }^{16 \sim 18)}$ 。この capsaicin の前処置によって, Y-25130の胃運動六進作用 は 1,10 および $100 \mu \mathrm{g} / \mathrm{kg}$ 投与において消失した。 ま た，迷走神経の電気刺激による胃収縮に対し，Y-25130 は求心性刺激においては $100 \mu \mathrm{g} / \mathrm{kg}$ 投与で増強作用を 示したが，遠心性刺激においては $100 \mu \mathrm{g} / \mathrm{kg}$ および 1 $\mathrm{mg} / \mathrm{kg}$ 投与で増強作用を示さなかった。 これらのこと から, Y-25130 の胃運動元進作用の作用点は迷走神経求 心性線維に存在しており, 最終点には迷走神経の興奮を 伴うあのであることが推察される.

シスプラチンは, 腸管壁内に存在するエンテロクロマ フィン細胞からの 5-HT の遊離を促進し, 内臓から延 䯣に至る求心性神経線維の $5-\mathrm{HT}_{3}$ 受容体を活性化する ことによって嘔吐を発現すると考えられている ${ }^{19)}$.5$\mathrm{HT}$ がラットの幽門部胃運動を抑制し, $5-\mathrm{HT}_{3}$ 受容体

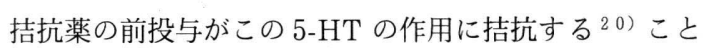
や, 今回得られた Y-25130 のラット胃運動六進作用に おける作用点が, シスプラチンの誘発する嘔吐の作用点 と類似しているところから，Y-25130 の制吐作用と胃運 動圥進作用之は何らかの関連性が窥えるが, その詳細は 不明であり今後の検討を待ちたい.

以上, ラット胃運動の自動解析システムを作製し, こ れを用いて選択的 $5-\mathrm{HT}_{3}$ 受容体拮抗薬である Y -25130 


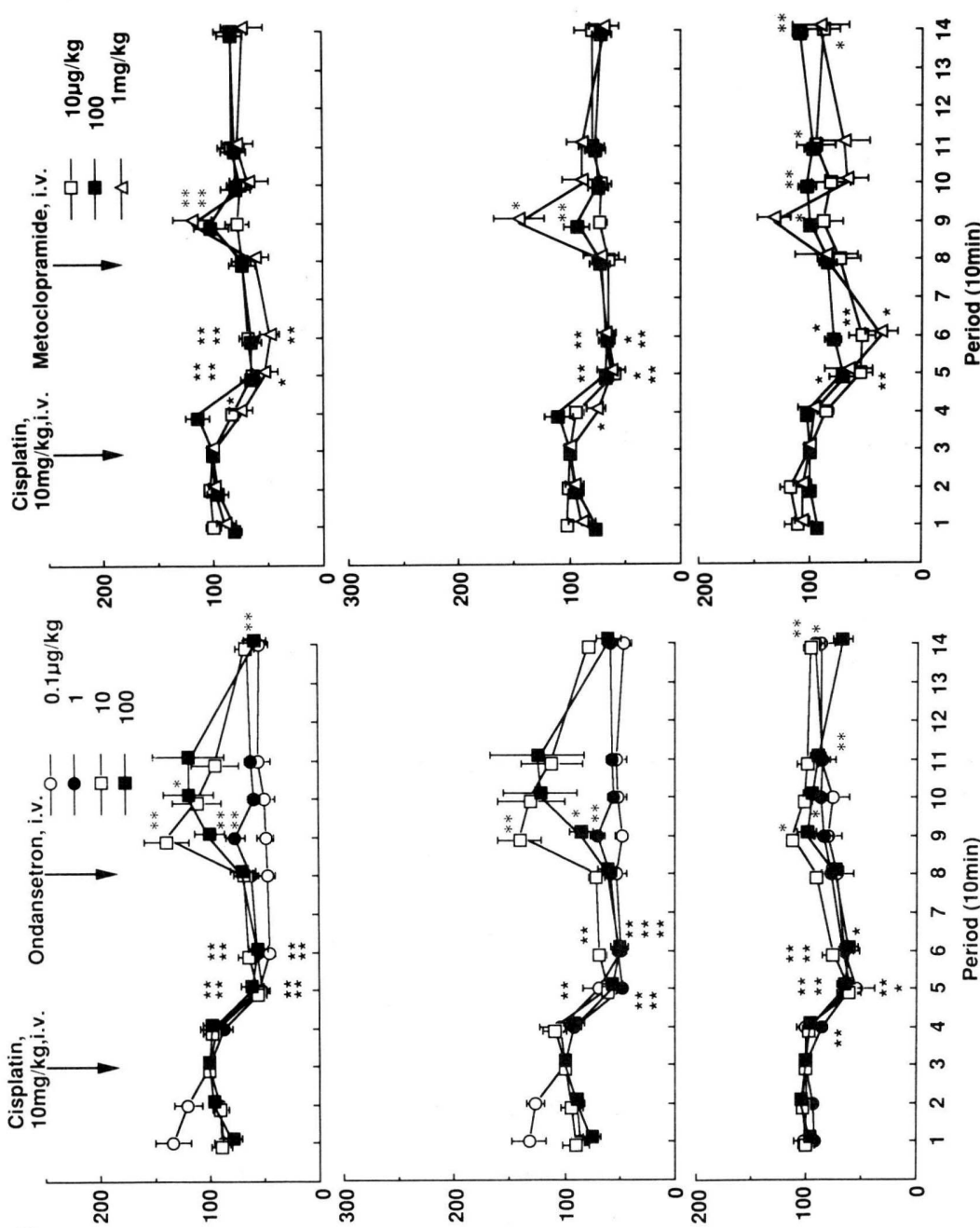

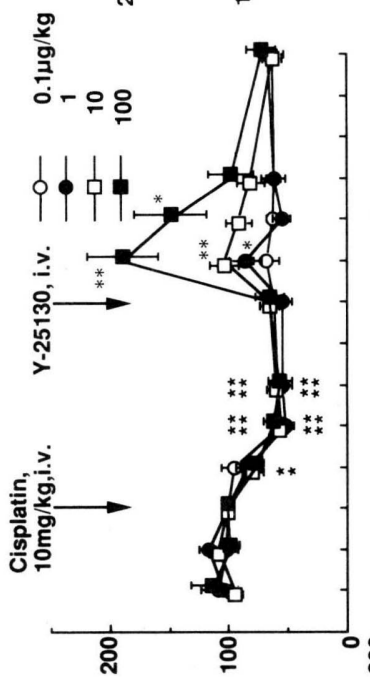

(\%) xәрu| K!!!!

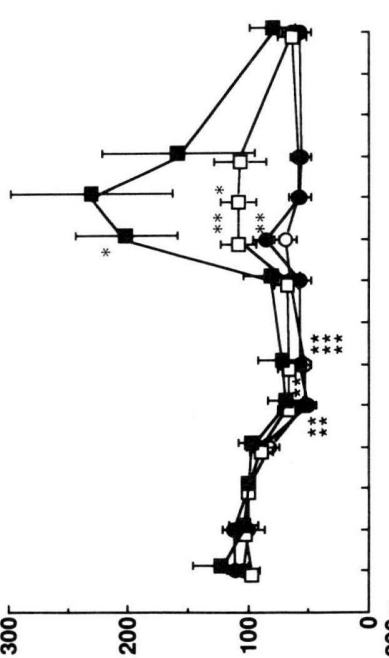

(\%) әрnџ!|duళ

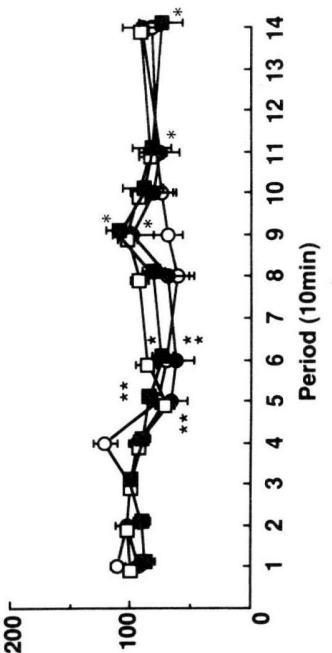

(\%) Aouenbedy

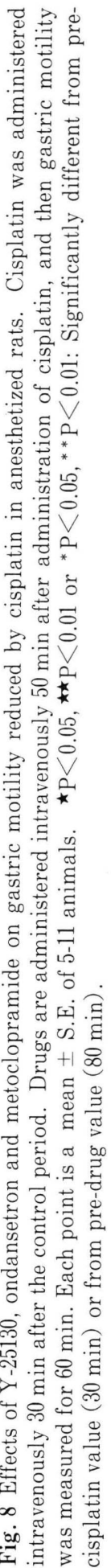




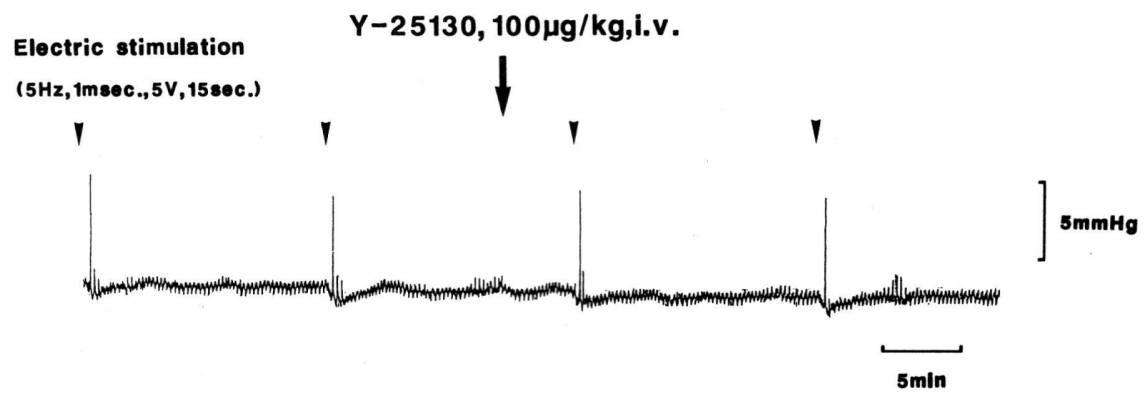

Fig. 9 Effect of Y-25130 on gastric motility induced by efferent vagus electric stimulation in a vagotomized rat. The vagus was stimulated every $15 \mathrm{~min}$, and Y-25130 was administered intravenously $10 \mathrm{~min}$ after the control stimulation.

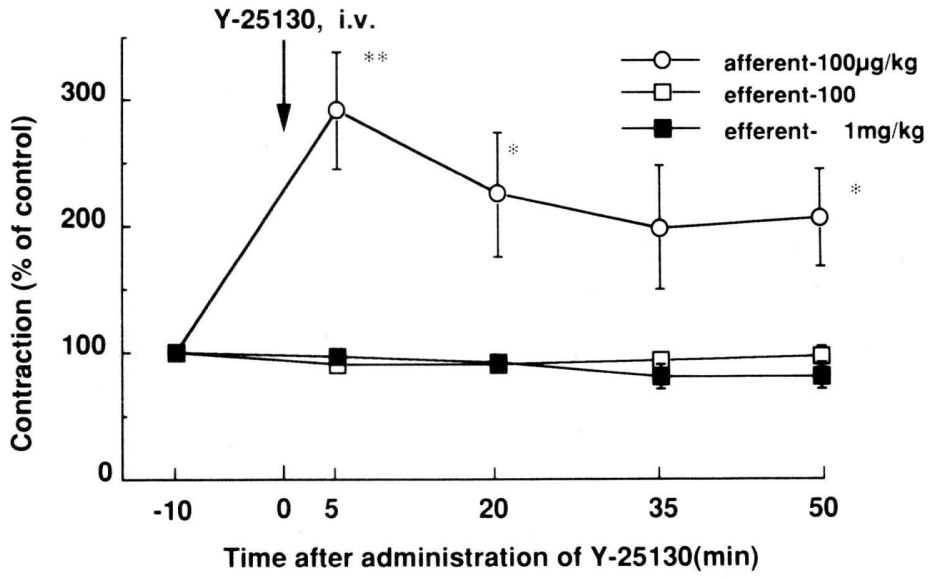

Fig. 10 Effect of Y-25130 on gastric motility induced by afferent or efferent vagus electric stimulation in anesthetized rats. Y-25130 was administered intravenously $10 \mathrm{~min}$ after the control stimulation, and then the vagus was stimulated every $15 \mathrm{~min}$ until $50 \mathrm{~min}$ after the administration. Each point is a mean \pm S.E. of 6-7 animals. ${ }^{*} \mathrm{P}<0.05,{ }^{*} \mathrm{P}<0.01$ : Significantly different from the control.

の胃運動穴進作用を明らかにした。また，その作用点は 迷走神経求心性線維に存在している $5-\mathrm{HT}_{3}$ 受容体であ ることが推察された。

謝辞 : 稿を終えるにあたり, 胃運動自動解析システムの 製作に協力していただいた笛田孝行氏をはじめユニック ス（株）の皆様に深謝いたします。

\section{文献}

1) Gaddum, J.H. and Picarelli, Z.P.: Two kinds of tryptamine receptors. Br. J. Pharmacol. Chemother. 12, 323 328 (1957)

2) Richardson, B.P. and Engel, G.: The pharmacology and function of 5 - $\mathrm{HT}_{3}$ receptors. Trends
Neurosci. 9, 424 428 (1986)

3）稲葉賢一, 森本保人, 福田武美, 瀬戸口通英 : 新規 Dihydrobenzoxazine carboxamide 誘導体, Y-25130 の von Bezold-Jarisch Effect における 5- $\mathrm{HT}_{3}$ 受容 体遮断作用. 日薬理誌 98, 293 299（1991）

4) Fukuda, T., Setoguchi, M., Inaba, K., Shouji, H. and Tahara, T.: The antiemetic profile of Y-25130, a new selective $5-\mathrm{HT}_{3}$ receptor antagonist. Eur. J. Pharmacol. 196, 299 305 (1991)

5) Brittain, R.T. et al.: GR-38032F, a novel selective $5-\mathrm{HT}_{3}$ receptor antagonist. Br. J. Pharmacol. 90, Supp. 87P (1987)

6) Costall, B., Naylor, R.J. and Tattersall, F.D.: The actions of fenfluramine and interaction with $5-\mathrm{HT}_{3}$ receptor antagonists to inhibit emesis in the ferret. J. Pharm. Pharmacol. 42, 94 101 (1990) 

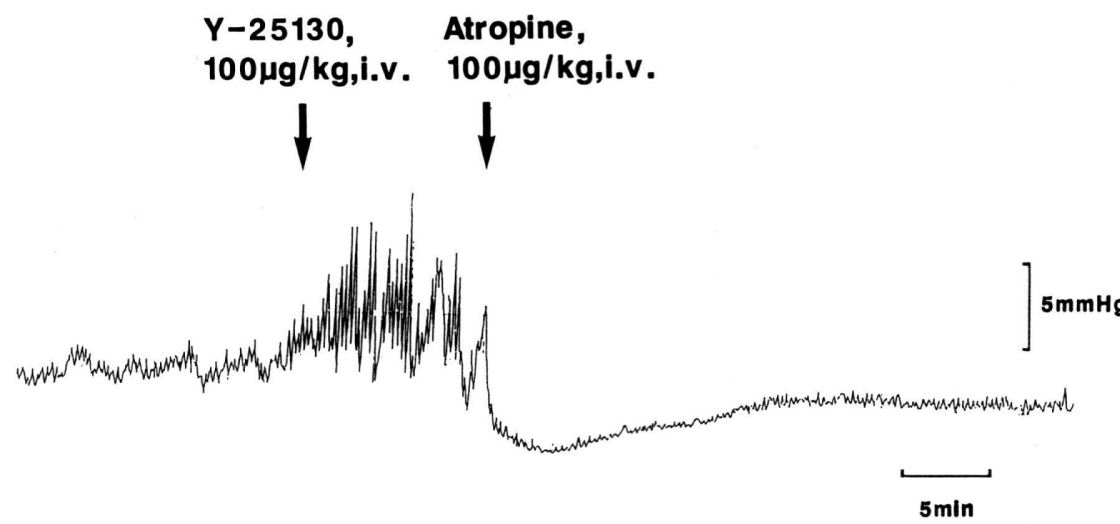

Fig. 11 Effect of atropine on gastric motility increased by Y-25130 in an anesthetized rat. Atropine was administered intravenously 10 min after administration of Y-25130.
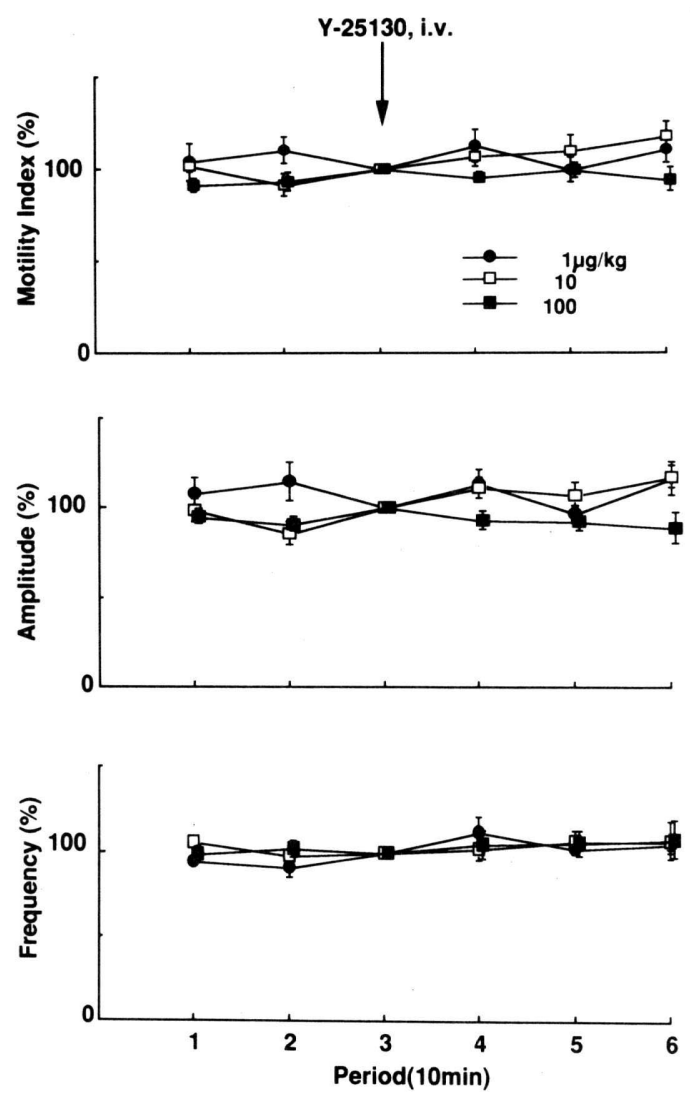

Fig. 12 Effect of Y-25130 on gastric motility in capsaicin pre-treated rats. Capsaicin was administered subcutaneously 2 weeks before the experiment. Y-25130 was administered intravenously after a 30 -min control period, and then gastric motility was measured for $30 \mathrm{~min}$. Each point is a mean \pm S.E. of 7 animals.
7）吉村 功：毒性薬効デー夕の統計解析。サイエン ティスト社, 東京 (1989)

8) Costall, B., Gunning, S.J., Naylor, R.J. and Tyers, M.B. : The effect of GR-38032F, novel 5- $\mathrm{HT}_{3}$ receptor antagonist on gastric emptying in guinea-pig. Br. J. Pharmacol. 91, 263 264 (1987)

9) Gidda, J.S., Evans, D.C., Prime, P., Schenck, K. and Cohen, M.L.: Role of $5-\mathrm{HT}_{3}$ receptor antagonist in gastrointestinal motility (abstr). Gastroenterology 95, A867 (1989)

10) Buchheit, K.H., Costall, B., Engel, G., Gunning, S. J., Naylor, R.J. and Richardson, B.P.: 5-Hydroxytryptamine receptor antagonism by metoclopramide and ICS 205-930 in the guinea pig leads to enhancement of contractions of stomach muscle strips induced by electrical field stimulation and facilitation of gastric emptying in-vivo. J. Pharm. Pharmacol. 37, 664 667 (1985)

11）木村永一, 宮本 篤，八田懭一, 大鹿英世: 消化管 運動に対する 5 - $\mathrm{HT}_{3}$ 受容体遮断薬 1,2,3,9-Tetrahydro-9-metyl-3- [ (2-methylimidazol-1-yl) methyl] carbazole-4-one, Hydrochloride, Dihydrate (SN307）の作用. 札坭医誌 58, 221 230（1989）

12) Borison, H.L., Borison, R. and McCathy, L.E.: Phylogenic and neurologic aspects of the vomiting process. J. Clin. Pharmacol. 21, 23S 29S (1981)

13) Eeckhout, C. and Vedder, A.: $5-\mathrm{HT}_{3}$ antagonists reverse the cisplatin induced slowing of gastric emptying in fed rats (abstr). Gastroenterology 95, A111 (1988)

14）竜田正治, 飯石浩康, 春日井博志, 奥田茂：体部 胃炎の病態に関する研究. Gastroenterol. Endoscopy 28, 508 515 (1986)

15) Magens, A.A.H.P., Canters, L.L.J., Artois, K.S. K., Smeyers, F., Keersmaekers, R.C.A. and Awouters, F.: Non-antidopaminergic, noncholinergic stimulation of gastric emptying with 
cisapride in rats. Drug Dev. Res. 8, 243 250 (1986)

16) Green, T. and Dockray, G.J.: Characterization of the peptidergic afferent innervation of the stomach in the rat, mouse and guinea-pig. Neuroscience 25, 181 193 (1988)

17) Buck, S.H. and Burks, T.F.: The neuropharmacology of capsaicin, review of some recent observations. Pharmacol. Rev. 38, 179 226 (1986)

18) Sharkey, K.A., Williams, R.G. and Dockray, G.J.: Sensory substance $\mathrm{P}$ innervation of the stomach and pancreas, demonstration of capsaicin sensitive sensory neurons in the rat by combined immuno- histochemistry and retrograde tracing. Gastroenterology 87, 914 921 (1984)

19) Miner, W.D. and Sanger, G.J.: Inhibition of cisplatin induced vomiting by 5-hydroxytryptamine M receptor antagonism. Br. J. Pharmacol. 88, 497 $\sim 499$ (1986)

20) Yoshioka, M., Ikeda, T., Togashi, H. and Saito, H.: Effect of 5-hydroxytryptamine on gastric motility and efferent gastric vagus nerve activity in rats. Res. Commun. Chem. Pathol. Pharmacol.70, $3 \sim 10(1990)$

Abstract - Effect of Y-25130 on gastric motility in anesthetized rats. Naoya ODANI, Keiichiro HAGA and Michihide SETOGUCHI (Research Laboratories, Yoshitomi Pharmaceutical Industries,Ltd., 955 Koiwai, Yoshitomi-cho, Chikujo-gun, Fukuoka 871, Japan). Folia pharmacol. japon. 101, 17 26 (1993)

We developed an automatic analyzing system using a personal computer to evaluate gastric motility objectively. Gastric motility was divided into three elements: motility index, amplitude and frequency. These elements analyzed with both computer and manual methods closely correlated with each other $\left(R^{2}=0.943\right.$, 0.985 and 0.986 , respectively). The effect of Y-25130 on gastric motility was investigated in anesthetized rats with the automatic analyzing system. Intravenous administration of Y-25130 increased both spontaneous and cisplatin-reduced gastric motility. The effect of Y-25130 on spontaneous motility was superior to that of ondansetron and metoclopramide, and the effect on cisplatin-reduced motility was almost the same as that of ondansetron and superior to that of metoclopramide. In vagotomized rats, Y-25130 did not increase the gastric motility not only in spontaneous conditions but also in efferent vagus stimulated conditions. Atropine completely blocked the gastric motility induced by Y-25130. In capsaicin pre-treated rats, Y-25130 had no effect. On the other hand, Y-25130 increased the gastric motility induced by afferent vagus stimulation. These results suggest that Y-25130 increases gastric motility through the vagus nerve and acts on afferent neurons. 